\title{
Semasiological Relations between the Lexical Parallels in the French and Russian Languages (A Case Study of the French Borrowed Vocabulary)
}

\author{
Anastasia V. Ageeva ${ }^{1}$, Liliya R. Abdullina ${ }^{1} \&$ Nyaz R. Latypov $^{1}$ \\ ${ }^{1}$ Kazan (Volga Region) Federal University, Kazan, Russia \\ Correspondence: Anastasia V. Ageeva, Kazan (Volga Region) Federal University, Kremlyovskaya street, 18, \\ Kazan 420008, Russia. E-mail: anastasia_ageeva@mail.ru
}

Received: April 14, 2015 Accepted: April 20, 2015 Online Published: April 27, 2015

doi:10.5539/jsd.v8n4p53 URL: http://dx.doi.org/10.5539/jsd.v8n4p53

\begin{abstract}
The relevance of the paper is determined by the intensification of international and intercultural contacts contributing to further promotion of the Russian language lexical system enrichment. The paper is devoted to the study and scientific analysis of neologisms of the French origin in the Russian language of modern period in terms of semantic adaptation of the foreign word in the recipient language. The basic mechanisms of reception and adaptation of the French language ethno-cultural components in the Russian language were identified through the analysis of various sources, including etymological, defining, and foreign dictionaries. This article describes four basic mechanisms of lexical-semantic assimilation of the foreign words in the Russian language environment (narrowing or expanding of the semantic range of a word; semantic structure sustainability; semantic shift). The study data of the article suggest the universal character of the proposed analysis criteria that can be applied to foreign language vocabulary of any language of any etymology.
\end{abstract}

Keywords: gallicism, prototype, correlate, adaptation, lexical meaning

\section{Introduction}

The problem of language contact and borrowings is one of the central issues in historical and modern lexicology. It is a common knowledge that borrowing is one of the most important universal sources of any language vocabulary replenishment.

This problem is particularly relevant in the Russian language of the contemporary history due to the dramatic socio-economic transformation of the Russian society, the development of international cooperation and intercultural communication. At present, close international cooperation contributes to an active process of enriching the vocabulary of the Russian language lexical units of foreign origin. English, French, German, and some oriental languages are singled out by the scientists as the dominant source languages.

Vocabulary of the French origin represents a significant corpus in the modern Russian standard language. The history of the Franco-Russian contacts, reflecting the political and economic relations between the two countries, intercultural relations between France and Russia, led to the emergence of quite a large number of Gallicisms in the Russian language. L.Galdi's words are still relevant: "... the systematic study of the Latin elements will significantly advance the analysis of all the words borrowed into the Russian language, as well as into other Slavic languages" (Galdi, 1958).

According to many scientists (Balalykina, 1998; Gabdreeva 2011; Granovskaya, 2006; Dimitrova, 1984; Ivanitskaya, 1980; Kinderevich, 1992; Krysin, 2000, 2008; Mileikovskaya, 1984; Roger, 1985) semantic assimilation occupies a central position compared to formal grammatical adaptation of a word, since it is associated with the conformity of the semantic structure of the foreign language unit to the new lexical-semantic system. Recently, there have been a lot of research works focused on describing the process of borrowing and analysis of lexical unit adaptation to the system of the recipient language (Ageeva, 2008; Andrianova, 2009; Gainullina, 2008; Gabdreeva et al., 2011, 2013; Marinova, 2012 et al.).

Our scientific vision also embraces research works that feature lexical-statistical analysis, describing the relationship between lexical units of different languages (Egorov, 2011), works which dwell on the 
characteristics of language contacts and dialogue between cultures (Karabulatova, Polivara 2013; Mukhametshina, Galimullina, 2014), as well as works dedicated to new genres and types of discourse requiring new ways of expression (Markoksiya, 2004; Hering, 2010; Abdullina, Ageeva, 2014; Abdullina et al., 2014).

\section{Materials and Methods}

During the research we applied the methods of linguistic description (observation, description, classification, comparison) and traditional for lexical and historical studies methods of lexical-semantic, comparative analysis and the method of synchronic analysis of the language. Some aspects of the problem under study were approached using statistical methods of quantitative and percentage analysis.

Our research is based on the concept developed by Leningrad scientists E.E. Birzhakova (1972), L.L. Koutina (1972), L.A. Voinova (1972), Y.S. Sorokin (1965), which we further elaborate and apply to the French material (Gabdreeva, 2011, 2013). It provides a comprehensive approach to the study of borrowed foreign vocabulary, combining phonetic, morphological and lexical-semantic aspects, and enables to trace common language trends and consistent patterns of linguistic change through the analysis of the particular words history.

Specific apparent features of the French vocabulary, as well as covert markers were identified and systematized following the works of the previous researchers (Krysin, 2000, 2008; Sorokin, 1965; Gabdreeva, 2011, 2013):

- letter combinations ya, фл, гл, ль (круассан, кулуары, фляк, гламур, глиссер, альтернат);

- initial э (эмансипе);

- final combination -аль, -ель, -ер, -он, -анс, -ант, -аж (аваль, гарант, антиперсипирант, хроникер, кассер, пелотон, конкорданс, винтаж, увраж, татуаж);

- prefixes сюр-, дез- (сюрреализм, дезинформация, дезинтеграция);

- particles премьер-, гала-, пресс-, порт-, аван- (премьер-министр, премьер-лига, гала-концерт, пресс-атташе, пресс-конференция, портмоне, портплед, аванпост, авангард);

- final vowel ю, и, о, е (меню, резюме, дефиле, бюстье, ню, травести, аниме, парео, индиго, бандо) et al.

However, many prototypes have no explicit formal features that should also be treated very carefully. They should not be seen in absolute terms because they may coincide with letter combinations in the original words. The key selection criterion was the principle of identification of the vocabulary of different etymology: phonetic-semantic correlation, i.e. similarity of content plane and expression plane of a prototype and a correlative word in the period of borrowing.

\section{Results}

As a rule, the assimilation of foreign language vocabulary results in transformation of its semantic structure. Comparative analysis of the semantic structure of a prototype (i.e. a French word) and a correlate (lexical innovation in the recipient language) serve to single out four types of correlation.

\subsection{Narrowing of Semantic Range}

The first group includes lexical units that have their semantic range being reduced or narrowed. By narrowing we mean both simplification of the semantic structure, reduction of the quantity of the word meanings, and narrowing, modification of semantic range.

Thus, in the Russian language the word кулуары means only "rooms (in the parliament, at congress), located outside the meeting room, intended for relaxation, informal meetings, exchange of ideas; informal conversation in well-informed civic circles" (Adamchik, 2007), in contrast to the French prototype, which has rather extensive semantic structure: couloir - 1. Passage ou dégagement en longueur dans un appartement, une maison, un lieu public, une voiture de chemin de fer etc. -2 . Passage étroit entre deux régions, deux pays. -3 . Zone d'une piste d'athlétisme délimitée par deux lignes parallèles et dans laquelle doit rester chaque concurrent pendant la course. -4. Bruits, conversations de couloirs, officieux (Larousse). The source of borrowing is the figurative meaning of the French prototype 'rumors, informal conversations in the corridors', which is absolutely not reasoned in terms of the recipient language having its own system of nominations for these realia, which determined monosemy of the borrowed word.

The same group includes noun noir, which is polysemic in French: 1. Couleur noire. - 2. Matière colorante de couleur noire. -3 . Etoffe noire, vêtement ou couleur de deuil. -4 . Obscurité, nuit. -5 . fam. Travail noir, marché noir. -6 . Fiction romanesque ou cinématographique qui unit des scènes de violence à la peinture réaliste de la société sordide. - 7. (avec une majuscule) Personne de la race noire (Larousse), while in the Russian language 
there is only one meaning of the word ryap functioning exclusively in the film and television industry, meaning "gloomy, pessimistic film".

The narrowing of the conceptual field of a foreign language word, as compared to the prototype, could be exemplified by the lexeme миллезим: millésime - chiffre indiquant l'année d'émission d'une pièce de monnaie, celle de la récolte du raisin ayant servi à faire un vin, celle de la production d'une voiture. Noun миллезим functions in the recipient language only in the field of winemaking denoting 'a year of the production of wine, brandy; wine, brandy, produced in a given year", which allows us register the narrowing of the word meaning due to its use only in a certain context.

\subsection{Extension of Semantic Range}

The second group comprises lexemes which are characterized by extension of the semantic range, i.e. development of semantic derivatives. Semantic development can be divided into two types according to its etymology: second borrowing and development of semantic innovations in the Russian language.

Second semantic borrowing is a linguistic phenomenon known since the middle of the $18^{\text {th }}$ century. Many researchers do not take into account the origin of the figurative meaning and suggest that semantic compounding is the principal or main feature of borrowing's adaptation, without specifying the nature of the second meaning. In our opinion, it is essential to determine the source of figurative meaning. The presence of semantic correlation between the prototype and Gallicism indicates adoption of the basic meaning, the ongoing semantic adaptation, eventually leading to the semantic delimitation, ordering of the meanings combination in the mind of a native speaker (Gabdreeva et al., 2013).

As an example, we will consider the word aкceccyap. It has the following semantic structure in the source language: accessoire - 1. Ce qui est accessoire. -2 . Pièce destinée à compléter un élément principal ou à aider à son fonctionnement. - 3. Elément qui s'ajoute à la toilette (sac, ceinture etc.) et avec laquel il s'harmonise par la couleur, la matière etc. -4 . Objet, élément du décor, des costumes, dans une mise en scène d'une pièce du théâtre, d'un film.

Noun arceccyap that appeared in the Russian language in the $19^{\text {th }}$ century (1835), was originally documented as having the meaning "details to the picture", "accessories which furnish the main item" (Kinderevich). The further development within the lexical system of the Russian language brings to the fore the second, figurative meaning in the source language: aкceccyap - 1. Item of the stage settings (spec.) - 2.metaphoric. Particular feature, detail accompanying something important or essential (Ozhegov). In the Russian language of the contemporary history lexeme aкceccyap has acquired another meaning, common in the fashion industry: "dress accessories - items that complement the suit (handbag, scarf, gloves, jewelry)," which was the result of second borrowing from the French language (compare «Elément qui s'ajoute à la toilette (sac, ceinture etc.) et avec laquel il s'harmonise par la couleur, la matière etc.»).

Pilote (пилот) - 1. Personne qui conduit un avion, une voiture de course. - 2. Professionnel qualifié qui guide les navires dans les passage difficiles, à l'entrée de ports. - 4. Personne qui sert de guide. - 5. Qui sert de modèle, qui ouvre la voie, se fait à l'essai: series pilotes. - 6. Pilote automatique - dispositif, généralement doté d'un gyroscope qui permet la conduite d'un avion sans intervention de l'équipage ; dispositif mécasnique ou électronique qui assure à un bateau la conservation d'un cap fixé, sans intervention humaine. Noun пилот was borrowed into the Russian language with the meaning "pilot controlling the aircraft." In the last decades of the $20^{\text {th }}$ century new meanings were acquired from the field of sport: "in auto racing, bobsleigh, carting - an athlete controlling a bob, a cart, a racing car," in television: "the first test release of TV shows, series; opening night."

French word résumé (резюме) has the meaning of «exposé donnant en peu de mots l'essentiel de ce qui a été dit ou écrit». It entered the Russian language with the meaning "a summary of the essence that has been said, read or written, a brief conclusion, the result or outcome of something." In the Russian language of the most recent period lexeme резюме takes on a new meaning: "a brief autobiography submitted by a candidate to take up a certain position." Noun résumé has no such seme in the source language: the French use the abbreviation CV from the Latin curriculum vitae.

Tricolore (триколор) - 1. Qui porte trois couleurs (bleu, blanc et rouge), emblême de la nation française, d'une fonction officielle. The lexical meaning is broader in the recipient language than in the source language: триколор means three-colour national flag. Such phrases as "the Russian tricolor", "Italian tricolor" are actively used in the Russian mass media, which affords ground to speak about the extension of the semantic field.

Oriflamme (орифламма) - 1. Bannière d'apparat, longue et effilée. - 2. hist. Enseigne féodale de l'abbaye de Saint-Denis, adoptée par les rois de la France du XII ${ }^{\mathrm{e}}$ au XV $\mathrm{XV}^{\mathrm{e}}$ siècle. The dictionaries of foreign words borrowed 
into the Russian language register both these meanings in the recipient language: 1 . Royal banner (standard) in medieval France; 2. Large flag hanging on a string across the street. Dictionaries of foreign words of the contemporary history have another seme which is absent in the French language, and, therefore, appeared in the Russian language as a semantic derivation of the second meaning following the development of the advertising business: "a large cloth or blanket (usually advertising materials), suspended on a rope stretched across the street between the buildings."

\subsection{Preservation of Semantic Structure}

The third group includes lexical units the semantic structure of which remains unchanged. Most words in this group can be attributed to the terminological vocabulary featuring semantic stability: thanks to the monosemy in the source language they are not compounded by additional connotations, nominate only one concept and retaining that particular meaning are borrowed into the Russian language:

Force majeure (форс-мажсор) - événement qu'on ne peut éviter et dont on n'est pas responsable. In the Russian language форс-мажор functions mainly in the field of law: "force majeure circumstances which cannot be foreseen, prevented or eliminated by virtue of any actions (natural disasters, for example) and are exempt from property liability for breach of contract or causing harm; circumstance that cannot be avoided."

Voyerisme (вуайеризм) - deviation sexuelle dans laquelle le plaisir est obtenu par la vision dérobée des scènes érotiques. In the Russian language the lexeme has the same meaning: voyeurism is a kind of sexual perversion: spying the erotic scenes in order to get sexual pleasure.

Bordereau (бордеро) - document d'enregistrement, état récapitulatif d'opérations financières, commerciales etc. In the recipient language it has a meaning similar to one of the prototype: "extract of accounting paperwork, accounts, etc.; inventory of converted securities (stocks, bonds, promissory notes) prepared by the bank, the banking office or broker.

Aval (аваль) - garantie donnée sur un effet de commerce ou lors d'un octroi d'un prêt, par un tiers qui s'engage à en payer le montant si celui-ci n'est pas acquitté par le signataire ou le bénéficiaire. The lexeme retains the meaning in the Russian language: "guarantee of a bill, made by a third party as a special guarantee letter."

Antiperspirant (aнmunepcnupaнm) - déodorant qui supprime les odeurs corporelles. Lexical meaning in the Russian language is identical to the French one: "deodorant to prevent perspiration."

Visagiste (визажист) - coiffeur, esthéticien dont la technique a pour but de mettre en valeur la spécificité d'un visage. In the recipient language it has the same meaning: "a makeup designer, makeup artist."

Garant (2apaHm) - qui sert la garantie à qch, aux actes de qn. In the Russian language it expresses the same meaning of "guarantor; state, institution or a person giving a guarantee of anything."

Déport (Denopm) - bourse. Commission payée par un vendeur à terme au prêteur des titres. In the Russian language the lexeme retains the meaning of "speculative stock exchange transaction for a particular period which is settled with view to slump of security prices in order to obtain the exchange rate difference."

Captage (каптаж) - travail qui a pour but de recueillir un fluide (eau, pétrole) pour l'utiliser. The word каптаж retains its lexical meaning of the Russian prototype: "engineering operations aimed at extracting of groundwater, oil, and gas to the surface for their subsequent use and processing; equipment designed for such operations (well, borehole, etc.).

Commis voyageur (коммивояжер) - représentant de commerce. The lexeme functions in the recipient language having the same meaning: "a traveling agent of a trading company, offering customers some products providing available samples and catalogs."

Connaissement (коносаменm) - écrit par lequel le capitaine ou son agent sertifie l'accueil de la charge pour le transporter. Lexical meaning in the Russian language is identical to the meaning in the source language: "bill of lading issued by the ship's captain or a representative of the transport company to be given to the consignor shipper as shipping receipt."

Croupier (крупье) - employé d'une maison de jeu qui dirige les parties, qui paie et ramasse l'argent pour le compte de l'établissement. The word dealer has the same meaning in the recipient language: "in a gambling house - a stickman, manager that monitors the game, gives the participants their gain and takes lost bets."

Culturisme (культуризм) - culture physique destinée plus spécialement à developper la musculature. In the recipient language retains the meaning of the prototype: "a system of physical exercises with different weights (dumbbells, kettlebells, barbells and others.) aimed at the muscular development." 
Couturier (кутюрье) - personne qui retouche ou confectionne les vêtements. The lexeme couturier is functioning in the similar meaning in the Russian language: "fashion designer meeting the requirements of the modern fashion."

Matraquage (матракаж) - répétition continue d'un slogan, d'une image publicitaire. The word матракаж is used in Russian with the same meaning as in French: "annoying, endlessly repeated TV commercial or radio advertising."

\subsection{Semantic Shift}

As for the fourth group we distinguish a class of interlingual homonyms or so-called false friends. In our view, direct Franco-Russian language contacts are also an important source of interlingual homonyms when the lexeme having an occasional meaning is borrowed into the recipient language, thus, changing both its semantic structure and the functioning sphere, which subsequently leads to a loss of links with the source language.

Analyzing the main tendencies of the Gallicisms functioning in translation of the $20^{\text {th }}$ century, N.V. Gabdreeva $(2001,2011,2013)$ explains the mechanism of formation of the second type of such translation discrepancies as follows: the French original texts of the $17^{\text {th }}$ century contain words borrowed into the Russian language in the $17^{\text {th }}-18^{\text {th }}$ centuries. Later (in the late $18^{\text {th }}-$ early $19^{\text {th }}$ centuries) the abovementioned Gallicisms extended its range due to the meanings reappropriation as a result of which the early meanings were replaced, i.e. the original, first meanings were archaized. For a time there was a combination of 2-3 meanings, sometimes linked by a common seme, sometimes they were distinctly different from each other. In the $20^{\text {th }}$ century as a result of polysemy rupture, when the meanings differed from the original ones or were lost in the recipient language, Gallicisms in connection with semantic transformations: narrowing of the semantic structure, development of new meanings, semantic derivation - no longer denoted the notion, relevant and meaningful in the $18^{\text {th }}$ century.

Needless to say that such changes take time, which foreign language vocabulary of modern period lacks. Probably, it is the reason for relatively small number of interlingual homonyms among the newest loanwords. As an example:

Frotté (фpome) - 1. Subi une pression de qch qui fait des mouvements. - 2. Enduit par frottement ou friction. Lexeme ppome is used in the Russian language with the meaning of "terry fabric, used for the manufacture of bathrobes, towels, sheets." It is fairly easy to trace the meaning community: French verb frotter also has the meaning "to wipe". French expression «tissu frotté» entered the Russian language as «ткань фроте» that later turned into just «ppome».

Glacé (глясе) - 1. Solidifié, durci par le froid. - 2. Très froid. - 3. Engourdi par le froid. - 4. Qui marque des dispositions hostiles ou au moins indifférentes. -5 . cuis. Recouvert d'un glaçage ou d'une glace ; confit dans du sucre. -6 . Qui a subi un glaçage brillant : papier glacé. In the Russian language this lexical unit is functioning in cooking having the meaning of "black coffee with ice cream."

Fourchette (фуричеm) - 1. Ustensile de table à dents pointues, dont on se sert pour piquer les aliments. - 2. stat. Ecart entre deux nombres, à l'intérieur duquel on fait une estimation. - 3. techn. Pièce mécanique à deux branches. This lexeme entered the Russian language expressing the meaning of "an appetizer; having a meal without sitting down at a table, standing." Most probably, the source of the borrowing was French expression avoir un bon coup de fourchette - «to be keen on eating well, to be a big eater." Adverbial composites are also functioning in the Russian language: alyafurshet (a la fourchette). They have the meaning of "not sitting at a table, in a hurry" - завтракать а-ля фуршет, ужинать а-ля фуршет.

Parole (пароль) - 1. Faculté naturelle de parler. - 2. Fait de parler. - 3. Possibilité, droit de parler dans un groupe, une assemblée. -4 . Capacité personnelle à parler, à s'exprimer oralement. -5 . Mot ou suite de mots, phrase. -6 . ling. Usage concret qu'un individu fait de la langue. - 7. Assurance donnée à qn. The word пароль was borrowed into the Russian language with the meaning "a secret word or phrase that is used to identify your people, in-crowd (in the military service or in conditions of conspiracy)." The following meaning was used as a prototype: «mot ou suite de mots, phrase». However, the lexeme has acquired another meaning in the Russian language, actively functioning in the field of computer science and computer engineering: "a certain combination of characters entered by the user into a computer to gain an access to data and programs", which ultimately contributed to the loss of semantic links between the borrowed word and the French prototype.

\section{Discussion}

The process of unit transition from one lexical system to another is usually divided by researchers into stages that determine the sequence and formal features inherent in the word at every stage. 
M. Martysyuk reckons that this process involves two main stages: the period of a foreign word entering the recipient language and its functioning there, i.e. borrowing of words, and then development of new meanings, as well as the use of loanwords in a figurative meaning (Martysyuk, 1978).

L.M.Rozhe distinguishes three stages of foreign words assimilation: transition; occurrence, characterized by the beginning of the gradual assimilation, extension of use; integration - complete adaptation to the rules of the borrowing language (Roger, 1985).

According to A.A. Ivanitskaya, the process of the lexeme development also encompasses three stages: the use of a foreign word in the utterance in another language; at this stage word is used episodically; the word is more or less mismatching a new system, i.e. heterogeneity - an indicator of foreign language element comprehension; integration (Ivanitskaya, 1980).

As follows from the analysis of lexical-semantic structure of the French prototype and the foreign word in the recipient language, the authors of this research come to conclusion that there are several important stages of the semantic adaptation of foreign words in the recipient language:

- The period of occurrence of the lexeme in the new language environment, when borrowed meanings get adopted to the new language system:

- Its functioning in the recipient language, development of new meanings, the loss of the old ones etc.

The initial period of the foreign language words adaptation is often characterized by refinement, specification of borrowed, sometimes too general meanings. There are many cases when no such changes occur, since the meanings coincide both in the source language and in the recipient language, especially when it comes to terminological vocabulary. At later stages foreign language vocabulary is developing as part of the lexical system of the borrowing language and functions as an originally Russian: new meanings are developed and the old ones are archaized. Under the influence of social changes in the borrowing environment it changes its semantic structure. As a result of the influence of extralinguistic factors (the development of certain fields of science, new technologies, intercultural communication) new meanings are often borrowed for the foreign words that already exist in the language. All these factors determine the status of the French foreign language vocabulary in the Russian language of the modern period.

\section{Conclusion}

The study of the research works on language contacts, analysis of lexicographical material (dictionaries of loanwords, defining dictionaries of the Russian language, economic, legal, psychological, and other dictionaries), and other supplementary resources (fiction, translations) suggest that the French vocabulary, which is a traditional layer of Russian lexical system, continues to enrich the vocabulary of the modern Russian standard language. Borrowings from the European languages are a natural phenomenon that occurs due to a number of external (extra-linguistic) and internal (language, linguistic) reasons. The most powerful external factor influencing the language development is the process of human culture development since the language as a social phenomenon is primarily destined to serve the needs of the society.

In this study, through the analysis of the history of individual words we attempted to trace the general rules of adaptation and development of the vocabulary of the French origin in the Russian language at the semantic level.

The present study outlines numerous research perspectives: it is possible to conduct a detailed study of the French foreign vocabulary represented in different materials: the press, advertisement, fiction, Internet discourse. In addition, we consider it promising and relevant to carry out a comparative study of adaptation mechanisms specific to vocabulary of different etymologies.

\section{Acknowledgments}

The work is performed according to the Russian Government Program of Competitive Growth of Kazan Federal University

\section{References}

Abdullina, L. R., \& Ageeva, A. V. (2014). Gallitsizmy kak sredstvo sozdaniya srednevekovoy kartiny mira v sovremennom russkoyazychnom fentezi. Vestnik YUUrGU. Seriya «Lingvistika», 11, 74-78.

Abdullina, L. R., Ageeva, A. V., \& Smirnova E. A. (2014). The Evolution of the "Comment" Genre: Theoretical Aspect. World Applied Sciences Journal, 29(3), 354-358.

Adamchik, V. V. (2007). Noveyshiy slovar' inostrannykh slov russkogo yazyka. Minsk: Sovremennyy literator. 
Ageeva, A. V. (2008). Inoyazychnaya leksika frantsuzskogo proiskhozhdeniya v russkom yazyke noveyshego perioda (Doctoral dissertation). Tatarskiy gosudarstvennyy gumanitarno-pedagogicheskiy universitet, Kazan', Rossiya.

Andrianova, N. S. (2009). Voyennaya i nauchno-tekhnicheskaya terminologiya frantsuzskogo proiskhozhdeniya $v$ sovremennom russkom yazyke (Doctoral dissertation). Tatarskiy gosudarstvennyy gumanitarno-pedagogicheskiy universitet, Kazan, Rossiya.

Balalykina, E. A. (1998). Semanticheskiye izmeneniya v predelakh zaimstvovannoy leksiki v russkom yazyke. Uchenyye zapiski Kazanskogo universiteta, 135, 30-39.

Birzhakova, E. E., Voynova, L. A., \& Kutina, L. L. (1972) Ocherki po istoricheskoy leksikologii russkogo yazyka XVIII veka. Yazykovyye kontakty i zaimstvovaniya. Leningrad: Nauka.

Dimitrova, T. R. (1984). Semanticheskoye osvoyeniye slov, zaimstvovannykh russkim i bolgarskim yazykami iz frantsuzskogo (Doctoral dissertation). Moskovskiy gosudarstvennyy universitet im. M. V. Lomonosova, Moskva, Rossiya.

Egorov, D. (2011). Automated dating of the world's language families based on lexical similarity. Current Anthropology, 52(6), 841-875. http://dx.doi.org/10.1086/662127

Gabdreyeva, N. V. (2011). Istoriya frantsuzskoy leksiki v russkikh raznovremennykh perevodakh. Moskva: Lenand.

Gabdreyeva, N. V., Ageyeeva, A. V., \& Timergaleyeva, A. R. (2013) Inoyazychnaya leksika v russkom yazyke noveyshego perioda. Moskva: Flinta: Nauka.

Galdi, L. (1958). Slova romanskogo proiskhozhdeniya v russkom yazyke. Moskva: Izdatelstvo Moskovskogo universiteta.

Gaynullina, N. I. (2008). Zaimstvovannaya leksika v Petrovskuyu epokhu. Problemy adaptatsii. Almaty.

Granovskaya, L. M. (2006). Gallitsizmy: sovremennyy etap zaimstvovaniya. Yazyk i my, 155-164.

Herring, S. C. (2010). Computer-mediated conversation: Introduction and overview. Language@Internet, 7. Retrieved from http:// www.languageatinternet.org/articles/2010/2801

Ivanitskaya, A. A. (1980). Zaimstvovaniye inoyazychnoy leksiki i yeye osvoyeniye (Doctoral dissertation). Kiyevskiy gosudarstvennyy universitet im. T. G. Shevchenko, Kiyev, Ukraina.

Karabulatova, I. S., \& Polivara, Z. V. (2013). Turkic and Slavs: Bi-Polylinguism in Globalization and Migrations (On an Example of Tumen Region). Middle-East Journal of Scientific Research, 17(6), 832-836.

Kinderevich, A. I. (1992). Gallitsizmy v russkikh perevodakh XIX veka (na materiale proizvedeniy frantsuzskikh pisateley) (Doctoral dissertation). Kazanskiy gosudarstvennyy universitet im. V.I.Ulyanova-Lenina, Kazan, Rossiya.

Krysin, L. P. (2000). O nekotorykh izmeneniyakh v russkom yazyke kontsa XX veka. Issledovaniya po slavyanskim yazykam, 5, 63-91.

Krysin, L. P. (2008). Sovremennyy russkiy yazyk: Aktivnyye protsessy na rubezhe XX-XXI vekov. Moskva: Yazyki slavyanskikh kultur.

Marcoccia, M. (2004). On-line Polylogues: conversation structure and participation framework in Internet. Newsgroups. Journal of Pragmatics, 36(1), 115-145. http://dx.doi.org/10.1016/S0378-2166(03)00038-9

Marinova, Y. V. (2012). Inoyazychnaya leksika sovremennogo russkogo yazyka: ucheb. posobiye. Moskva: Flinta: Nauka.

Martysyuk, M. (1978). Kharakteristika nemetskikh zaimstvovannykh imen sushchestvitel'nykh v russkom yazyke. Poznan: Widawnistwo Naukowe Uniwersytetu im. Adama Mickiewicza.

Mileykovskaya, G. M. (1984). Polskiye zaimstvovaniya v russkom literaturnom yazyke XV-XVIII vekov. Varshava.

Mukhametshina, R. F., \& Galimullina, A. F. (2014). Inculcation of Bimental personality in context of cultural dialogue (as exemplified by Tatarstan Schools). Middle-East Journal of Scientific Research, 20(12), 2135-2138. 
Rozhe, L. M. (1985). Aspekty izucheniya zaimstvovaniy v russkom yazyke i optimizatsiya ikh leksikograficheskogo predstavleniya (Doctoral dissertation). Universitet druzhby narodov im. Patrisa Lumumby, Moskva, Rossiya.

Sorokin, Y. S. (1965). Razvitiye slovarnogo sostava russkogo literaturnogo yazyka: 30-90-ye gody XIX veka. Moskva: Nauka.

\section{Copyrights}

Copyright for this article is retained by the author(s), with first publication rights granted to the journal.

This is an open-access article distributed under the terms and conditions of the Creative Commons Attribution license (http://creativecommons.org/licenses/by/3.0/). 